\title{
Pleomorphic Variant Mantle Cell Lymphoma
}

National Cancer Institute

\section{Source}

National Cancer Institute. Pleomorphic Variant Mantle Cell Lymphoma. NCI Thesaurus.

Code C39747.

An aggressive mantle cell lymphoma characterized by the presence of pleomorphic neoplastic B-lymphocytes. 